\title{
APXITEКTУРA
}

УДК 721:72.012.8

DOI: $10.30838 / J . B P S A C E A .2312 .250918 .113 .203$

\section{SECURITY AND AUTOMATIC PASSENGER PROCESSING SYSTEMS IN MODERN TERMINALS DESIGN}

QASIM MOHAMMED BASIM, Ph.D. candidate

faculty of architecture, Kyiv national university of construction and architecture, ORCID ID 0000-0002-3223-646x

Summary. In this article a new solutions and systems presented to design a fully automatic controlled terminals, starting from how to maximize the security level and automatic central control the terminal faculties accesses and control the passengers flow, to make a short-timed path in the terminal by automatic gates and doors without human intervention, increasing the passnegers flow and minimize the long waiting time of the security screening in the airports, forming a terminal with an open space design without partitions and clear paths for passengers, reducing the working staff and reusing the planned spaces in the terminal for the staff to another uses and functions.

Keywords: passenger terminals; organization of passenger-flows; airport; security systems; automatic controlled terminals; passenger processing; terminal design

\section{СИСТЕМИ БЕЗПЕКИ Й АВТОМАТИЧНОЇ РЕССТРАЦЇ̈ ПАСАЖИРІВ У ДИЗАЙНІ СУЧАСНИХ ТЕРМІНАЛІВ}

КАСИМ МОХАММЕД БАСИМ, асnір.

Архітектурний факультет, Київський національний університет будівництва і архітектури, ORCID ID 0000-0002-3223-646x

Анотація. Наведено нові рішення і системи для проектування повністю автоматизованих керованих терміналів, починаючи з того, як максимізувати рівень безпеки й автоматичне центральне управління об'єктів термінала, і контролювати потік пасажирів, щоб зробити короткий тайм-маршрут у терміналі, збільшуючи потік пасажирів і мінімізуючи тривалий час очікування, формування безпеки в аеропортах, утворюючи термінал із відкритим простором без перегородок і чітких шляхів для пасажирів, скорочуючи робочий персонал і використовуючи запланований простір у терміналі для персоналу та інших функцій.

Ключові слова: пасажирські термінали; організація пасажирських потоків;аеропорт; системи безпеки; термінали з автоматичним управлінням; реєстрація пасажирів; дизайн термінала

\section{СИСТЕМЫ БЕЗОПАСНОСТИ И АВТОМАТИЧЕСКОЙ РЕГИСТРАЦИИ ПАССАЖИРОВ В ДИЗАЙНЕ СОВРЕМЕННЫХ ТЕРМИНАЛОВ}

КАСИМ МОХАММЕД БАСИМ, аспир.

Архитектурный факультет, Киевский национальный университет строительства и архитектуры, ORCID ID 0000-0002-3223-646x

Аннотация. Представлены новые решения и системы для проектирования полностью автоматизированных управляемых терминалов, начиная с того, как оптимизировать уровень безопасности и автоматического центрального управления объектами терминалов и контролировать поток пассажиров, чтобы сделать короче маршрут в терминале. Автоматические ворота и двери используются без вмешательства человека, увеличивая поток пассажиров и минимизируя длительность времени ожидания безопасности в аэропортах, образуя терминал с открытым пространством без перегородок и четких путей для пассажиров, сокращая рабочий персонал и используя запланированные пространства в терминале для персонала в других функциях.

Ключевые слова: пассажирские терминалы; организация пассажирских потоков; аэропорт; системы безопасности; терминалы с автоматическим управлением; регистрация пассажиров; дизайн терминала

Introduction. Security requirements at airport have continued to increase in the recent years, the airports security systems in these days is one of the most advanced technology systems with a central concern of staff access control and passengers individual access checks. Airports operators are looking to maximize the flow of people through their 
terminals while maintaining high safety standards. At the same time architects and planning teams are constantly striving for an open, welcoming look space for the passengers, visitors and staff expect access controls to be quick and user-friendly taking into consideration the functional side. Satisfying these different requirements is a challenge nowadays.

The modern solutions focus on control the access to all different areas in the airport and organize the increasing passengers' flow year after year and applying the maximum security standards and quick respond to the threats using the latest technology. and as well as organizing the large number of airport staff.

Airport entrance. Airport entrances have to be much more than just simple doors, it must concern the architecture of the building, have an attractive design, optimum insulation and high throughput rate and barrier - free entry for luggage and people with reduced mobility and prams.

Building entrances create several challenges for airports - and entry is just one of them: another challenges for example: Climate control, energy saving, and attractive design with integration into the façade of the building, concerning Safety of people while entering and exiting the building with good emergency exit management and evacuation.

Automatic sliding doors are an effective and popular solution for airport entrances. They are user - friendly and safe and also maintain a smooth flow of people - even at the busiest of times. As the door wing close immediately after passengers and staff have walked through the entrance, energy loss is kept to a minimum.

- High throughput rate.

- Easy access

- Good thermal insulation

- Transparent design

- Emergency escape options

- Access for people with reduced mobility [1]

Other solutions which recommended for airport entrances are large revolving and circular sliding doors, include signs which blend in with virtually any style of modern façade architecture. Airport entrance doors must have manually and full automatic movement control with approved emergency escape functions. (pic. 1)

Automated boarding pass control gates. Passengers' flow can be improved by automatic boarding pass control as passengers enter the departure zone and proceed towards security screening.

Boarding pass control gates support airport staff in checking passengers' boarding passes more efficiently. In turn, this reduces queues at the departure hall entrance, eliminating congestion and making it easier for the airport security units to stay in control. Half-height sensor barriers with automatic swing panels, an integrated boarding pass reader and a display for passenger information. (pic. 1)

- System prevents misuse of boarding cards. It detects, for instance, double use.

- By scanning the boarding card, the system can inform the relevant airlines with the whereabouts of the passenger. The information can be used to decide whether luggage should be taken off the aircraft for late passengers.

- First / business class, VIPs and airline staff can be managed separately, reducing waiting times.

- Passengers' flow is improved, reducing congestion and queues outside the departure hall.

- Gate allows passage with trolley, backpack and other luggage without alarm.

- Operators can profit from detailed reporting on passage, tailgating or attempt of passage in the wrong direction. [2]

Passport control and border management. Security at passport control desks has to be maintained rigorously. All such as security check points, including those designed for people with reduced mobility gate taxis and the transit of goods, have to be easy and safe to use.

Swing doors and tripod barriers provide the ideal solutions to guide and control the flow of the passengers at the passports control desks.

Double swing doors are ideal for access points intended to be used by gate taxis and for the goods and can be only be activated by the airport staff. (pic.1) 
- Stylish, transparent design

- Access for the people with reduced mobility

- Easy passage thanks to power-assisted drive

- Opening time and angle adjustable

Border management. Entry and exit channels require visual identification checks by immigration stuff and are therefore one of the most sensitive and time-consuming aspects of passenger processing at airports.

New solutions with automatic passenger control which speed up the border controls and cut waiting times at check points and allow selected passengers, such as frequent travelers to pass through the check points using automatic identification systems

These solutions combine different technological systems used in physical access control, automatic document readers and biometry.

To use the system, passengers place their passport or identity card on the document reader at the entrance to the check point cubicle. Data is scanned from the document and the passenger is then allowed to enter the cubicle by the first door. Within the interlock system, the document information is verified by means of biometrical devices. If the results of the scan match the passenger details, they can leave the interlock area through a second door. If access not granted, the passenger is let through a side door to the usual manual passenger control check point. [3]

VIP lounges. Many airports have facilities for relaxing, as well as office areas for first and business class passengers. In order to control access to these select areas, a range of different entry systems are designed.

Circular sliding outer door and smokeproof inner sliding door. The outer door can be equipped with frosted glass to prevent the lounge from being seen from the outside, passengers activate the outer door release by placing their boarding pass or frequent flyer card in the reader. By the interlocking function, the inner door only open once the outer door has closed. (Pic. 1)

- All-glass versions for an extra stylish look
- Access for people with reduced mobility possible

If staff support is available at VIP lounge entrances, automatic sliding doors are the ideal solution. A vast range of designs and configurations are available to suit all requirements. [4]

Boarding gates. Large numbers of passengers have to be admitted at the boarding gates in the shortest time possible, fast, userfriendly equipment is essential to help airport staff to check each individual passenger. This is why many terminals have installed automatic units at boarding gates.

Tripod barriers, the barrier release is activated when a valid boarding pass is placed in the reader -either by airport staff or by passenger using the (quick boarding) system for frequent flyers. When pushed lightly the barrier turns automatically to let the passenger through and then stops, reading the next passenger. (Pic. 1).

To provide easy access for groups of passengers or for the transit of goods, the barrier can be collapsed at the touch of the button.

- Collapsible bars with automatic reset functions

- Unit opens even under pressure

- Suitable for installation in escape routes

- Matching automatic swing doors for access for people with reduced mobility.

Passage from the air to the land. One of the most sensitive aspects of airport security is maintaining the division between the public area (land side) and the security area (airside). On arrival at their destination, passengers should be able to leave the plane and cross over quickly and easily from the air to the land side. Security regulations stipulate that the flow of passengers should be organized is such a way that no unauthorized individuals can gain access to the air side.

One-way corridor was developed to control the transfer of the passengers arriving at the air terminal. It allows for fast, safe passage from the air to the land side. (Pic. 1) 


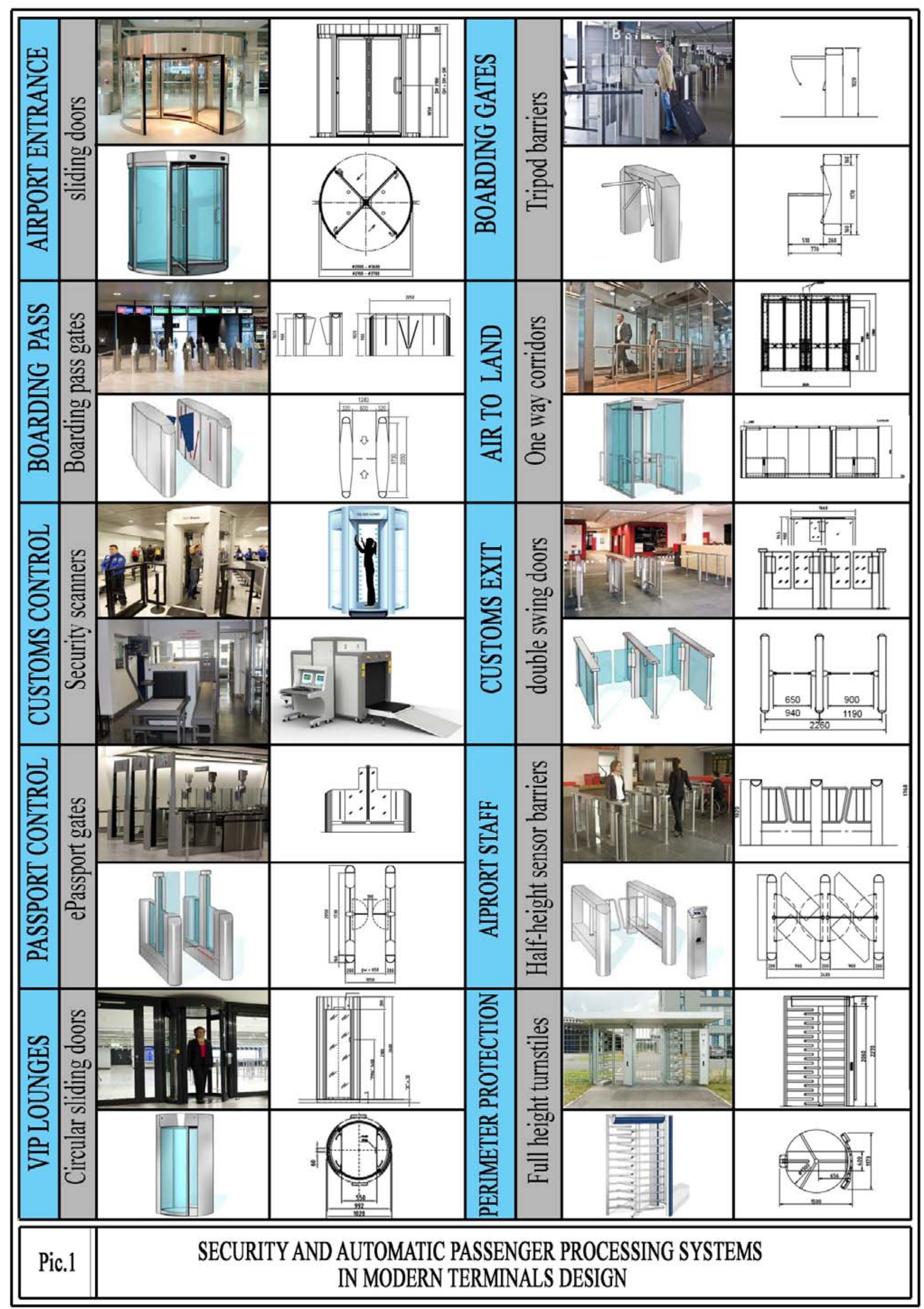


This modular system consists of lane scanned by sensors and equipped with a range of rapid-access doors such as full-height and half-height double swing doors. When passengers cross from the air to the land side, these doors open automatically one after the other and close once passengers have passed through. Its sophisticated system of sensors provides and effective barrier to prevent anyone crossing unnoticed from the land to the airside.

- cutting - edge design.

- customized configuration

- smooth, barrier-free passage

- maximum safety for the user

- sensor prevent people from being injured by the door leaf

- modular system: combination of different doors possible. [5]

Customs exit. After claiming baggage, passengers pass through customs control to the landside. In this area, the flow of the passengers should be managed in a way that prevents people on the landside from being able to reach the baggage reclaim area. Passengers should, however, be able to pass through this area, pushing baggage trolleys and carrying their suitcases, without hindrance. For this reason, a fully automatic door system is essential.

Automatic doors provide the perfect solution for exit points from the baggage reclaim area. A range of designs and configurations are available to suit all requirements.

Automatic double swing doors are often installed on the land side to provide a welcoming user-friendly exit. (Pic. 1)

- Stylish, transparent design.

- Access solution for people with reduced mobility.

- Door wings open automatically towards the landside, opposite direction locked.

- Opening time and angle fully adjustable. [6]

Channels for aiprort staff. Staff only entrances and exits are lucked along the division between the public and security areas. These doors are not generally subject to constant staff surveillance and therefore require security units for access control.
Half-height sensor barriers. This equipment is used mainly in areas which are within the sight of reception staff such as office area of the airport. This unit is a sensor-controlled passage way with automatic half-height swing doors. (Pic. 1)

- Easy passage, even with bags or luggage.

- No contact with swing panel.

- High throughput rate and maximum safety for users

- Variety of colors, shapes and finishes

- High level of user acceptance.

- Access for people with reduced mobility.

Another solution for staff access control is revolving security doors, these electronicallymonitored revolving doors allow for fast and efficient access control. The door release is activated by placing an airport staff card in the reader. The door wings turn and lock automatically after every release.

- Column certificated for escape in emergency situations.

- Patented end-point locking system prevents bring locked in.

- All glass units with under-floor drive

- Option with night shutters. [7]

For the highest security level recommended personal interlocks-card readers or biometrical devices can be used for access control.

- Reinforced units for protection against vandalism, burglary, firearms and fire

- Two zone contact mat for additional security.

- Installation for scales to record weight limits for additional security or exact weight for the highest security level.

- Option with fire resistant shutters.

- All-glass units for an extra stylish look. [8]

Visitors' terrace. A visitors' terrace is a common attraction for guests at many airports. Admission to this area is generally granted by passing through a half-height door with access control, which is often programmed with special functions. 
To keeping the open space value in the terminal, half- height turnstiles can be used, when access has been granted, all it takes is a light push and the power-assisted drive automatically turns the rotating degree unit $90^{\circ}$. automatic swing doors are ideal for access for people with reduced mobility or prams. (Pic. 1)

- Space-saving double unit.

- Optimum flow of visitors

- Optional coin validation function release after payment of an entrance fee.

- Optional counter: turnstile locks in the entrance direction when the maximum number of visitors is reached.

Perimeter protection and accesses. Every airport is surrounded by extensive grounds the need to be protected against unauthorized entry. Entrances along the perimeter fence, which provide access for airport staff, vehicles, deliveries, external companies, etc. can be problematic as far as security is concerned. Access con- trol units for these check points must therefore be functional robust and weather proof.

Full height turnstiles equipped with card readers and ID scanners are the ideal solution for efficiently protecting the outside area. A key feature of the centaur range is its modular system, which makes it extremely versatile. Included in the specification options for these products are a range of turnstile bars available in classic curved or modern straight form, and a choice of materials for the side panels and entrance unit that houses the card reader, intercom or signal devices. (Pic. 1)

Various elements and a number of other options are also can be applied.

- Patented end-point locking system prevents being locked in

- Sturdy and durable

- Turnstile column and bars made of stainless steel

- $\quad$ Two three or four winged versions

- Power assisted versions available. [9]

\section{REFERENCES:}

1. Sarah N. and Shuchi A. Novel Concept for Airport Terminal Design Integrating Flexibility: a thesis ... for the degree of Doctor of Philosophy (Civil Engineering). Queensland University of Technology. Queensland, 2015.

2. Long-Wen Chen. Airport design: a thesis ...for the degree of Master of Fine Arts Rochester Institute of Technology. New York, 1999.

3. Planning and design guidelines for airport terminal facilities .US Federal aviation administration. Washington D. C. 1988.

4. Physical Access Systems: [catalog] Dormakaba Holding. Rümlang. 2015, 47 p. Available at: file://D:/\%D0\%97\%D0\%B0\%D0\%B3\%D1\%80\%D1\%83\%D0\%B7\%D0\%BA\%D0\%B8/fotoheft-pas-32167.pdf

5. KABA. Sistemy fizicheskogo kontrolya dostupa [Resheniya dlya aeroportov][Systems of physical access [Solutions for airport]]. Available at: http://basys.ua/?page_id=749. (in Russian).

6. Hee King Jim and Zeph Yun Chang. An airport passenger terminal simulator: A planning and design tool. Simulation Practice and Theory, 1998, vol. 6, iss. 4, p.p. 387-396.

7. Kirk Philip J. Passenger Experience at Airports: An Activity-Centered Approach: thesis ... for the degree of Doctor of Philosophy (Research). Queensland University of Technology. Queensland, 2013, 199 p.

8. Hereford Peggy G. New International Terminal for Los Angeles. Airport Forum. 1980, vol. 10, no. 5.

9. Kortan J. F. Atlanta's New Central Passenger Terminal Complex. Journal of Transportation Engineering (J TRANSP ENG-ASCE). 1980, vol. 106, no. 6.

\section{ВИКОРИСТАНА ЛІТЕРАТУРА}

1. Shuchi Sarah N. A Novel Concept for Airport Terminal Design Integrating Flexibility : a thesis ... for the degree of Doctor of Philosophy (Civil Engineering) / Sarah N. Shuchi ; Queensland University of Technology. - Queensland, 2015. - $264 \mathrm{p}$.

2. Chen Long-Wen. Airport design : a thesis ... for the degree of Master of Fine Arts / Long-Wen Chen ;; Rochester Institute of Technology. - New York, 1999. - $67 \mathrm{p}$.

3. Planning and design guidelines for airport terminal facilities : advisory circular ; AC no. 150/5360-13 / U.S. Department of Transportation i Federal Aviation Administration. - [Date Cancelled July 13, 2018 ; Date Issued April 22, 1988]. - Washington, D. C, 1988. - 148 p. 
4. Physical Access Systems : [catalog] / Dormakaba Holding. Rümlang. - 2015. - 47 p. - Режим доступа: file:///D:/\%D0\%97\%D0\%B0\%D0\%B3\%D1\%80\%D1\%83\%D0\%B7\%D0\%BA\%D0\%B8/fotoheft-pas32167.pdf.

5. КАВА - системы физического контроля доступа [Решения для аэропортов]. - Режим доступа: http://basys.ua/?page_id=749.

6. Hee King Jim. An airport passenger terminal simulator: A planning and design tool / Hee King Jim, Zeph Yun Chang // Simulation Practice and Theory. - 1998. - Vol. 6, iss. 4. - P. 387-396.

7. Kirk Philip J. Passenger Experience at Airports: An Activity-Centered Approach : thesis ... for the degree of Doctor of Philosophy (Research) / Philip James Kirk ; Queensland University of Technology. Queensland, 2013. - $199 \mathrm{p}$.

8. Hereford Peggy G. New International Terminal for Los Angeles / Hereford Peggy G. // Airport Forum. 1980. - Vol. 10. - № 5.

9. Kortan J. F. Atlanta's New Central Passenger Terminal Complex / J. F. Kortan // Journal of Transportation Engineering (J TRANSP ENG-ASCE). - 1980. - Vol. 106. - № 6.

Рецензент: Дьомін М. М., д-р архітектури

Надійшла до редколегії: 17.04.2018 р. 